\title{
Kondisi dan Keanekaragaman Jenis Lamun di Perairan Pulau Serangan, Provinsi Bali
}

\author{
Luh Gede Manik Radzena Martha ${ }^{\text {a*, }}$ Pande Gde Sasmita Julyantoro a, \\ Alfi Hermawati Waskita Sari a \\ a Program Studi Manajemen Sumberdaya Perairan, Fakultas Kelautan dan Perikanan, Universitas Udayana, Kampus UNUD Bukit Jimbaran, \\ Bali 80361, Indonesia \\ * Penulis koresponden. Tel.: +62-812-372-3120 \\ Alamat e-mail: manikradzena@gmail.com
}

Diterima (received) 4 Desember 2017; disetujui (accepted) 15 September 2018; tersedia secara online (available online) 19 September 2018

\begin{abstract}
Serangan Island is one of the tourism destinations in Bali which is administratively belong to the municipality of Denpasar. Tourism development near with the segrass habitat cause the segrass ecosystem being degraded in the waters of Serangan Island. This study was aimed to determine the diversity and conditions of seagrass species which were observed from the density and percentage of seagrass coverage and to examine the effect of water quality on the percentage of seagrass coverage. This research was conducted from February to March 2017 on Serangan Island using quantitative descriptive method. Sampling was conducted at three stations by taking data and samples of seagrass, measuring water quality (temperature, salinity, $\mathrm{pH}$, turbidity, substrate observation) and analyze of nitrates and phosphates content. Seven types of seagrass species were found i.e. Enhalus acoroides, Thalassia hemprichii, Cymodocea rotundata, Halophila ovalis, Halodule pinifolia, Syringodium isoetifolium, and Thalassodendron ciliatum. The study showed that the diversity index value was in the medium category. The density of seagrass was classified as very tight (condition scale of 5). The highest density was found on Cymodocea rotundata spesies at station I about $777 \mathrm{ind} / \mathrm{m}^{2}$. The highest percentage of seagrass coverage $(79,55 \%)$ was found in station I which classified as good condition, while station II and station III were classified as damaged condition with value $13.65 \%$ and $20,79 \%$ respectively. Finally, the water quality parameters have relatively low effect to seagrass coverage percentage.
\end{abstract}

Keywords: seagrass; diversity; water quality; Serangan Island

\begin{abstract}
Abstrak
Pulau Serangan merupakan salah satu destinasi Pariwisata di Bali yang secara administratif masuk ke dalam wilayah Kotamadya Denpasar. Pengembangan pariwisata yang berdekatan dengan habitat padang lamun di Perairan Pulau Serangan menyebabkan ekosistem padang lamun terdegradasi. Penelitian ini bertujuan untuk mengetahui keanekaragaman jenis dan kondisi padang lamun dilihat dari kerapatan dan persentase tutupan lamun serta mengkaji pengaruh kualitas perairan terhadap persentase tutupan lamun. Penelitian ini dilaksanakan bulan Pebruari sampai Maret 2017 di Pulau Serangan menggunakan metode deskriptif kuantitatif. Pengambilan sampel dilakukan di tiga stasiun dengan mengambil data dan sampel lamun, pengukuran kualitas perairan (suhu, salinitas, $\mathrm{pH}$, kekeruhan, pengamatan substrat) dan uji kandungan nitrat $\left(\mathrm{NO}_{3}\right)$ dan fosfat $\left(\mathrm{PO}_{4}\right)$ pada perairan. Spesies lamun yang ditemukan ada tujuh jenis yaitu Enhalus acoroides, Thalassia hemprichii, Cymodocea rotundata, Halophila ovalis, Halodule pinifolia, Syringodium isoetifolium, dan Thalassodendron ciliatum. Nilai indeks keanekaragaman dalam kategori sedang. Kerapatan padang lamun tergolong dalam skala kondisi 5 yaitu sangat rapat. Kerapatan jenis tertinggi yaitu jenis Cymodocea rotundata pada stasiun I dengan jumlah $777 \mathrm{ind} / \mathrm{m}^{2}$. Nilai persentase tutupan lamun tertinggi terdapat pada stasiun I yang tergolong dalam kondisi baik yakni sebesar 79,55\%, stasiun II dan stasiun III tergolong dalam kondisi rusak dengan nilai 13,65\% dan 20,79\%. Parameter kualitas air memberikan pengaruh yang relatif rendah terhadap persen tutupan lamun.
\end{abstract}

Kata Kunci: lamun; keanekaragaman; kualitas perairan; Pulau Serangan 


\section{Pendahuluan}

Lamun (seagrass) merupakan merupakan tumbuhan berbiji (angiospresmae) yang berbunga dan hidup pada perairan dangkal yang masih mendapatkan cahaya matahari sehingga mampu menghantarkan zat-zat hara, oksigen dan menggangkut hasil metabolisme lamun pada lingkungan sekitarnya (Hartati et al., 2012; Rahman et al., 2016; Wagey, 2013). Di Indonesia terdapat 7 marga dan terdiri dari 13 jenis lamun (Yusniati, 2015). Salah satu lokasi penyebaran padang lamun di Bali ada di Pulau Serangan (Faiqoh, 2017).

Perairan Pulau Serangan termasuk pada ekosistem pesisir yang banyak dimanfaatkan untuk berbagai aktifitas manusia, pariwisata serta pembangunan dan reklamasi Pulau Serangan yang berdampak pada kondisi padang lamun yang mengakibatkan banyak terjadinya degradasi (Rahardiarta et al., 2019). Selain itu kegiatan budidaya rumput laut di Pulau Serangan yang menggunakan metode lepas dasar dan metode apung dapat menutupi dan menghilangkan lamun sehingga lamun cenderung mengalami kematian serta penambatan dan penjangkaran perahu dalam jangka waktu lama pada areal padang lamun secara langsung mematikan lamun yang ada di bawah kapal (Sudiarta, 2011).

Rendahnya pengetahuan masyarakat mengenai pentingnya ekosistem padang lamun menyebabkan ekosistem ini kurang mendapat perhatian. Padahal lamun memiliki fungsi sebagai tempat berlindung sekaligus memijah, tempat berkembangbiak, daerah pengasuhan dan tempat mencari makan khususnya bagi biota perairan laut sekaligus makanan kesukaan hewan herbivora (Alie, 2012). Penelitian ini menjadi penting dilakukan untuk mengetahui keadaan atau kondisi padang lamun di Perairan Pulau Serangan sehingga sebagai dapat menjadi informasi dalam pengembangan dan pemanfaatan wilayah pesisir di Pulau Serangan guna menjaga kelestarian ekosistem padang lamun. Penelitian ini bertujuan untuk mengetahui keanekaragaman jenis dan kondisi padang lamun dilihat dari kerapatan dan persentase tutupan lamun serta mengkaji pengaruh faktor lingkungan terhadap persentase tutupan lamun di Perairan Pulau Serangan.

\section{Metode Penelitian}

\subsection{Waktu dan Tempat}

Penelitian ini dilaksanakan di Pulau Serangan pada bulan Februari sampai bulan Maret 2017. Penelitian ini dilakukan di tiga stasiun yang telah ditentukan dengan masing-masing karakteristik yang berbeda (Gambar 1).

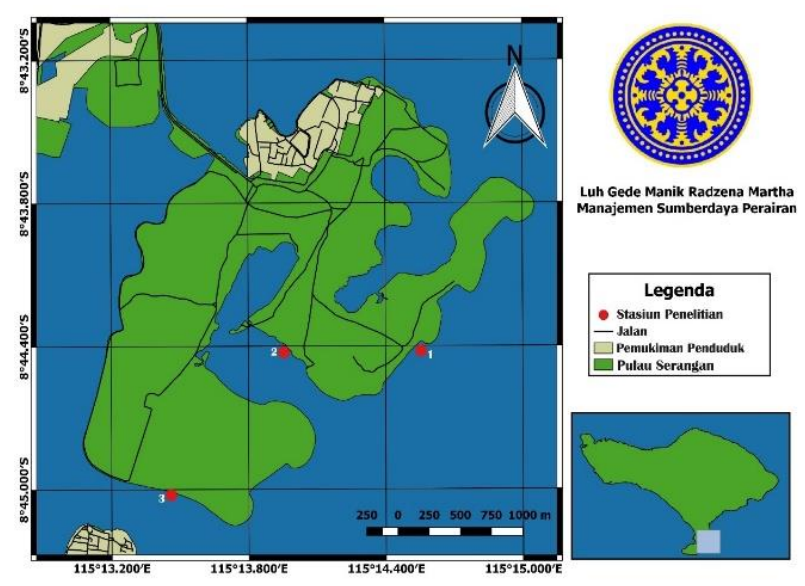

Gambar 1. Peta lokasi penelitian

Stasiun penelitian di Perairan Pulau Serangan dibagi menjadi 3 stasiun, yaitu:

Tabel 1

Stasiun Penelitian

\begin{tabular}{|c|c|}
\hline Stasiun & Gambaran Lokasi \\
\hline $\begin{array}{l}\text { Stasiun I } \\
8^{\circ} 44^{\prime} 23^{\prime \prime S} \\
115^{\circ} 14^{\prime} 33^{\prime \prime E}\end{array}$ & $\begin{array}{l}\text { Bagian Pantai Serangan yang } \\
\text { dimanfaatkan sebagai tempat } \\
\text { wisata. Hal ini ditunjukkan oleh } \\
\text { adanya beberapa bangunan tempat } \\
\text { makan dan aktivitas berenang serta } \\
\text { surfing. }\end{array}$ \\
\hline $\begin{array}{l}\text { Stasiun II } \\
8^{\circ} 44^{\prime} 26^{\prime \prime} S \\
115^{\circ} 13^{\prime} 57^{\prime \prime} \mathrm{E}\end{array}$ & Daerah budidaya rumput laut. \\
\hline $\begin{array}{l}\text { Stasiun III } \\
8^{\circ} 45^{\prime} 01^{\prime \prime S} \\
115^{\circ} 13^{\prime} 25^{\prime \prime E}\end{array}$ & $\begin{array}{l}\text { Terletak di bagian selatan Pulau } \\
\text { Serangan yang berbatasan langsung } \\
\text { dengan kawasan pariwisata Tanjung } \\
\text { Benoa dimana banyak terdapat } \\
\text { aktivitas water sport dan lewatnya } \\
\text { kapal-kapal besar yang hendak } \\
\text { menuju Pelabuhan Benoa. }\end{array}$ \\
\hline
\end{tabular}

\subsection{Waktu dan Tempat}

Alat dan bahan yang digunakan dalam penelitian ini adalah transek kuadran $1 \times 1 \mathrm{~m}$, alat tulis, 
gambar identifikasi lamun, kamera, cool box, turbidity, refraktometer, $\mathrm{pH}$ (derajat keasaman) meter, GPS, botol sampel, kertas label, roll meter dan kantong plastik. Kemudian untuk bahan penelitian yaitu lamun sebagai objek yang diteliti dan sampel air yang diukur kadar nitrat dan fosfat dalam perairan.

\subsection{Metode Penelitian}

Penelitian ini menggunakan metode deskriptif kuantitatif. Metode penentuan stasiun menggunakan metode purposive sampling yaitu penentuan stasiun berdasarkan kriteria atau pertimbangan tertentu (Sugiyono, 2012). Penelitian dilakukan pada tiga stasiun yang ditetapkan berdasarkan keterwakilan penyebaran lamun, variasi jenis, tingkat kerapatan lamun secara visual dan karakteristik masing-masing stasiun yang berbeda.

\subsubsection{Tahapan Penelitian}

Penelitian ini dilaksanakan dalam beberapa tahap yaitu identifikasi, pengambilan data lapangan, dan uji laboratorium.

\section{a. Identifikasi}

Tahap pertama yang dilakukan dalam penelitian ini adalah identifikasi permasalahan yang dapat mempengaruhi ekosistem padang lamun dan melihat keberadaan lamun di sekitar Perairan Pulau Serangan. Mempelajari serta mengkaji pustaka - pustaka yang berkaitan dengan penelitian. Setelah mengidentifikasi permasalahan dilakukan penentuan stasiun pengamatan. Setiap stasiun mewakili kondisi lingkungan perairan yang berbeda.

\section{b. Pengambilan Data Lapangan}

Pengambilan sampel lamun menggunakan transek kuadran $1 \mathrm{~m}$ x 1m yang dibagi menjadi 25 petak contoh, dan pengamatan dilakukan pada 5 petak contoh yang telah ditentukan. Mengidentifikasi dan mencatat jenis dan jumlah tegakan setiap jenis lamun yang ditemukan. Kemudian dilakukan estimasi persentase luas tutupan lamun menggunakan metode seagrass percent cover standards (McKenzie et al., 2003).

Pengukuran kualitas perairan dilakukan pada setiap stasiun yaitu suhu dan $\mathrm{pH}$ air dengan menggunakan $\mathrm{pH}$ meter. Pengukuran salinitas air dengan menggunakan refraktometer. Pengukuran kekeruhan diukur dengan turbidity meter.
Penentuan jenis substrat dilakukan pengamatan secara visual. Pengambilan sampel air sebanyak 1,5 liter yang digunakan untuk pengukuran Nitrat $\left(\mathrm{NO}_{3}\right)$ dan Fosfat $\left(\mathrm{PO}_{4}\right)$. Sampel air kemudian dibawa dan diujikan di Laboratorium Kesehatan Provinsi Bali.

c. Uji Laboratorium

Uji Nitrat $\left(\mathrm{NO}_{3}\right)$ dan Fosfat $\left(\mathrm{PO}_{4}\right)$ sampel air Pulau Serangan dilakukan di UPT Laboratorium Kesehatan Provinsi Bali. Pengujian nitrat menggunakan metode Brucine (Kusumaningtyas, 2010). Pengujian fosfat $\left(\mathrm{PO}_{4}\right)$ menggunakan metode Amm-Molybdat (Ardiani, 2014).

\subsection{Analisis Data}

\subsubsection{Indeks Keanekaragaman}

Keanekaragaman jenis lamun dihitung menggunakan indeks keanekaragaman ShannonWiener (Odum, 1993) dengan rumus:

$$
H^{\prime}=-\sum_{n=1}^{s} P i \ln P i
$$

dimana $\mathrm{H}^{\prime}$ adalah indeks keanekaragaman Shannon-Wiener; Pi adalah Ni/N; Ni adalah jumlah individu spesies ke-I; $\mathrm{N}$ adalah jumlah total individu; dan $\mathrm{S}$ adalah jumlah spesies.

\subsubsection{Indeks Keseragaman}

Indeks keseragaman lamun dapat dihitung dengan rumus (Odum, 1993):

$$
E=-\frac{H^{\prime}}{H m a k s}
$$

dimana $\mathrm{E}$ adalah indeks ieseragaman; $\mathrm{H}^{\prime}$ adalah indeks keanekaragaman; dan Hmaks adalah Indeks keanekaragaman maksimum $\left(\mathrm{H}_{\text {maks }}=\ln \mathrm{S}\right.$, dimana $S$ = jumlah jenis)

\subsubsection{Indeks Dominansi}

Indeks dominansi dapat dihitung menggunakan persamaan Indeks Dominansi Simpson (Odum, 1993), yaitu sebagai berikut:

$D=\sum_{i=1}^{n}\left(\frac{N i}{N}\right)^{2}$

dimana $\mathrm{D}$ adalah Indeks dominansi simpson; $\mathrm{Ni}$ adalah Jumlah individu jenis ke-i; dan $\mathrm{N}$ adalah jumlah total individu seluruh jenis 


\subsubsection{Kerapatan Jenis}

Kerapatan jenis merupakan perbandingan antara jumlah total individu dengan unit area yang diukur. Kerapatan jenis lamun dapat dihitung dengan persamaan:

$$
D i=\frac{n i}{A}
$$

dimana Di adalah kerapatan jenis (ind $\left./ \mathrm{m}^{2}\right)$; ni adalah jumlah individu (tegakan) ke $-\mathrm{i}$ dalam transek kuadrat; dan A adalah luas transek kuadrat $\left(\mathrm{m}^{2}\right)$.

Berdasarkan formulasi di atas, kerapatan lamun dikategorikan atas nilai-nilai sebagai berikut:

Tabel 2

Skala kondisi padang lamun berdasarkan kerapatan

\begin{tabular}{ccc}
\hline Skala & Kerapatan $\left(\mathrm{ind} / \mathrm{m}^{2}\right)$ & Kondisi \\
\hline 5 & $>175$ & Sangat rapat \\
4 & $125-175$ & Rapat \\
3 & $75-25$ & Agak rapat \\
2 & $25-75$ & Jarang \\
1 & $<25$ & Sangat Jarang \\
\hline
\end{tabular}

Sumber: Haris dan Gosari 2012

\subsubsection{Persentase Tutupan Lamun}

Penutupan lamun merupakan estimasi persentase luasan dalam plot transek yang tertutupi lamun, dihitung dengan menggunakan rumus:

$$
C=\frac{\sum(\operatorname{Mix} f i)}{\sum f}
$$

dimana $\mathrm{C}$ adalah persentase tutupan; $\mathrm{Mi}$ adalah nilai tengah kelas penutupan ke-i; fi adalah frekuensi penutupan lamun; dan $\Sigma \mathrm{f}$ adalah jumlah frekuensi penutupan lamun dalam plot.

Data hasil perhitungan tutupan lamun diketahui untuk menentukan status padang lamun menurut Kepmen LH No. 200 tahun 2004, dapat dilihat pada Tabel 3.

\section{Tabel 3}

Status padang lamun

\begin{tabular}{lll}
\hline & Kondisi & Penutupan (\%) \\
\hline Baik & Kaya/sehat & $\geq 60$ \\
Rusak & Kurang kaya/ & $30-59,9$ \\
& kurang sehat & \\
& Miskin & $\leq 29,9$ \\
\hline
\end{tabular}

2.4.6. Pengaruh Kualitas Perairan terhadap Persentase Tutupan Lamun

Analisis yang digunakan untuk mengetahui hubungan antara kualitas air terhadap persentase tutupan lamun dilakukan melalui analisis korelasi. Sementara untuk mengetahui pengaruh kualitas air terhadap persentase tutupan lamun adalah dengan menggunakan analisis regresi linier sederhana menggunakan Ms. Excel. Variabel bebas (tidak terikat) diberi notasi $\mathrm{x}$ yang merupakan kualitas air. Variabel yang tidak bebas (terikat) diberi notasi y adalah persen tutupan lamun. Analisis korelasi dapat dilihat sebagai berikut:

$$
r=\frac{n \sum(x i y i)-\left(\sum x i\right)\left(\sum y i\right)}{\sqrt{\left[n \sum x i^{2}-\left(\sum x i\right)^{2}\right]\left[n \sum y i^{2}-\left(\sum y i\right)^{2}\right]}}
$$

dimana $\mathrm{r}$ adalah koefisien korelasi; $\mathrm{x}$ adalah parameter kualitas air; $y$ adalah persen tutupan lamun; dan $\mathrm{n}$ adalah banyaknya pasangan data $\mathrm{x}$ dan y.

Nilai $\mathrm{r}$ (koefisen korelasi) menunjukkan hubungan variabel independen dengan variabel dependen. Sementara $R^{2}$ (koefisien determinasi) menunjukkan persentase sumbangan pengaruh variabel independen terhadap variabel dependen (Ulfa, 2018).

Tabel 4

Kriteria korelasi menurut Mulyadi (2011):

\begin{tabular}{ll}
\hline \multicolumn{1}{c}{$r$} & \multicolumn{1}{c}{ Kriteria hubungan } \\
\hline$<0,20$ & Hubungan dapat dianggap tidak ada \\
$0,20-0,40$ & Hubungan ada tetapi lemah \\
$>0,40-0,70$ & Hubungan cukup \\
$>0,70-0,90$ & Hubungan kuat \\
$>0,90-1,00$ & Hubungan sangat kuat \\
\hline
\end{tabular}

Untuk mengetahui seberapa besar pengaruh kualitas air terhadap persen tutupan lamun dilakukan analisis regresi. Analisis regresi dapat dilihat sebagai berikut:

$\bar{Y}=a+b x$

dimana:

$a=\frac{\left(\sum y\right) \sum x^{2}-\left(\sum x\right)\left(\sum x y\right)}{n \sum x^{2}-\left(\sum x\right)^{2}}$ 
$b=\frac{n \sum x y-\left(\sum x\right)\left(\sum y\right)}{n \sum x^{2}-\left(\sum x\right)^{2}}$

dimana $\bar{Y}$ adalah peubah tak bebas; $x$ adalah peubah bebas; a adalah perpotongan sumbu y bila nilai $x=0$; dan $b$ adalah nilai perubah variabel $y$ bila variabel $x$ berubah satu satuan.

Mengintepretasikan model regresi digunakan koefisien determinasi $\left(R^{2}\right)$ yang dapat dilihat sebagai berikut:

$$
R^{2}=\frac{a \sum y+b \sum x y-n(\bar{Y})^{2}}{\sum y^{2}-n(\bar{Y})^{2}}
$$

\section{Hasil dan Pembahasan}

\subsection{Keanekaragaman Jenis Lamun}

Jenis-jenis lamun yang ditemukan di Pulau Serangan pada masing-masing stasiun tersaji pada Tabel 5. Pada masing-masing stasiun setelah seluruh transek digabungkan maka memiliki komposisi kombinasi spesies penyusunnya berbeda-beda. Dilihat dari stasiun I hingga III, variasi spesies yang ditemukan di stasiun I paling tinggi dibandingkan dengan stasiun lainnya. Sementara pada stasiun III memiliki variasi spesies yang paling rendah diantara stasiun lainnya.

Jenis-jenis lamun yang ditemukan di Perairan Pulau Serangan pada semua stasiun sebanyak 7 jenis yaitu Enhalus acoroides, Thalassia hemprichii, Cymodocea rotundata, Halophila ovalis, Halodule pinifolia, Syringodium isoetifolium, dan Thalassodendron ciliatum. Jenis Syringodium isoetifolium dan Thalassodendron ciliatum hanya ditemukan pada stasiun I. Syringodium isoetifolium pada stasiun I hanya ditemukan pada transek yang berada dekat dengan pesisir. Dasar perairan stasiun I yang tidak rata sehingga banyak terdapat cekungan-cekungan yang tergenang air pada saat surut dan sebagian besar Syringodium isoetifolium ditemukan pada bagian perairan yang tergenang air dengan menempel pada substrat yang berkarang. Syringodium isoetifolium ditemukan pada daerah dangkal di hamparan terumbu. Jenis ini hanya mampu mentoleransi kekeringan dalam waktu yang sangat singkat (Hartati et al., 2017).
Tabel 5

Jenis-jenis lamun yang ditemukan di Perairan Pulau Serangan

\begin{tabular}{clccc}
\hline \multirow{2}{*}{ No. } & \multicolumn{2}{c}{ Jenis Lamun } & \multicolumn{3}{c}{ Stasiun } \\
\cline { 3 - 5 } & & I & II & III \\
\hline 1 & Enhalus acoroides & - & + & + \\
2 & Thalassia hemprichii & + & + & - \\
3 & Cymodocea rotundata & + & + & + \\
4 & Halophila ovalis & + & + & + \\
5 & Halodule pinifolia & + & + & + \\
6 & Syringodium isoetifolium & + & - & - \\
7 & Thalassodendron ciliatum & + & - & - \\
\hline
\end{tabular}

Keterangan: + = ada; - = tidak ada

Thalassodendron ciliatum pada stasiun I ditemukan menempel pada substrat yang berkarang. Thalassodendron ciliatum biasanya terdapat pada lingkungan sublittoral stabil (Sakaruddin, 2011). Pada stasiun I yang minim aktivitas manusia sehingga lingkungan lebih stabil Berbeda dengan stasiun II dan stasiun III yang terdapat gangguan dari aktivitas manusia.

Pada stasiun I, spesies lamun yang tidak ditemukan adalah Enhalus acoroides. Hal ini dikarenakan substrat pada stasiun ini dominan karang sehingga rhizome dari Enhalus acoroides tidak dapat menempel dengan baik. Enhalus acoroides dominan hidup pada substrat dasar berpasir dan pasir sedikit berlumpur dan kadangkadang terdapat pada dasar yang terdiri atas campuran pecahan karang yang telah mati (Tangke, 2010).

Spesies lamun yang tidak ditemukan pada stasiun III yaitu Thalassia hemprichii. Thalassia hemprichii mempunyai distribusi kedalaman yang sempit, mulai daerah eulitoral bawah sampai kedalaman $5 \mathrm{~m}$ (Hartati, 2017). Pada stasiun III dengan tipe pantai yang tidak landai dan jika pasang menjadikan stasiun ini memiliki kedalaman yang tinggi sehingga jenis lamun ini tidak dapat hidup.

Nilai indeks keanekaragaman di Perairan Pulau Serangan dikategorikan sedang yaitu berkisar antara 1,24 - 1,30. Nilai indeks keseragaman berkisar antara 0,72-0,89 yang termasuk ke dalam tingkat keseragaman tinggi karena nilainya lebih besar dari 0,6. Nilai indeks keseragaman menandakan bahwa tidak ada jenis lamun yang mendominasi dan perbadaan jumlah jenis yang tidak terlalu tinggi. Apabila semakin kecil indeks keseragaman maka semakin besar perbedaan 
Tabel 6

Indeks keanekaragaman, Indeks Keseragaman, dan Indeks Dominasi

\begin{tabular}{|c|c|c|c|c|c|c|}
\hline \multirow{2}{*}{ No. } & \multirow{2}{*}{ Indeks } & \multirow{2}{*}{ Nilai } & \multirow{2}{*}{ Kategori } & \multicolumn{3}{|c|}{ Stasiun } \\
\hline & & & & $\mathbf{I}$ & III & III \\
\hline 1 & Keanekaragaman $\left(\mathrm{H}^{\prime}\right)$ & $\begin{array}{l}\mathrm{H}^{\prime} \leq 1 \\
1 \leq \mathrm{H}^{\prime} \leq 3 \\
\mathrm{H}^{\prime}>3\end{array}$ & $\begin{array}{l}\text { Rendah } \\
\text { Sedang } \\
\text { Tinggi }\end{array}$ & $\begin{array}{c}1,30 \\
\text { (Sedang) }\end{array}$ & $\begin{array}{c}1,27 \\
\text { (Sedang) }\end{array}$ & $\begin{array}{c}1,24 \\
\text { (Sedang) }\end{array}$ \\
\hline 2 & Keseragaman (E) & $\begin{array}{l}0 \leq \mathrm{E} \leq 0,4 \\
0,4<\mathrm{E} \leq 0,6 \\
0,6<\mathrm{E} \leq 1,0\end{array}$ & $\begin{array}{l}\text { Rendah } \\
\text { Sedang } \\
\text { Tinggi }\end{array}$ & $\begin{array}{c}0,72 \\
\text { (Tinggi) }\end{array}$ & $\begin{array}{c}0,79 \\
\text { (Tinggi) }\end{array}$ & $\begin{array}{c}0,89 \\
\text { (Tinggi) }\end{array}$ \\
\hline 3 & Dominansi (D) & $0 \leq \mathrm{D} \leq 0,4$ & Rendah & $\begin{array}{c}0,33 \\
\text { (Rendah) }\end{array}$ & $\begin{array}{c}0,32 \\
\text { (Rendah) }\end{array}$ & $\begin{array}{c}0,32 \\
\text { (Rendah) }\end{array}$ \\
\hline
\end{tabular}

jumlah antara spesies (adanya dominansi) (Tishmawati, 2014).

Nilai indeks keseragaman yang tinggi berarti terjadi keseimbangan yang tinggi pada komposisi individu pada tiap jenis penyusunnya. Keadaan ini diikuti dengan nilai indeks dominansi yang rendah yaitu berkisar antara 0,32 - 0,33. Dominansi yang rendah menandakan kondisi lingkungan di Perairan Pulau Serangan yang stabil sehingga tidak terjadi tekanan ekologis terhadap biota di perairan tersebut dan tidak terdapatnya spesies lamun yang secara ekstrim mendominasi spesies lainnya (Tabel 6).

\subsection{Kondisi Lamun di Perairan Pulau Serangan}

\subsubsection{Kerapatan Jenis Lamun}

Kondisi kerapatan lamun di Perairan Pulau Serangan termasuk dalam skala 5 dengan nilai kerapatan $>175$ ind $/ \mathrm{m}^{2}$ yang berarti lamun di Perairan Pulau Serangan tergolong lamun dengan kondisi sangat rapat, skala kerapatan lamun diketahui untuk menentukan kondisi padang lamun. Kerapatan jenis lamun tertinggi ditemukan pada jenis Cymodocea rotundata pada stasiun I dengan jumlah 777 ind $/ \mathrm{m}^{2}$. Kemudian kerapatan jenis lamun terendah ditemukan pada jenis Thalassia hemprichii pada stasiun II dengan jumlah $4 \mathrm{ind} / \mathrm{m}^{2}$ (Tabel 7).

Kerapatan lamun Cymodocea rotundata pada stasiun I memiliki perbedaan jumlah yang sangat signifikan dengan stasiun lainnya. Menurut Wicaksono (2012), jenis Cymodocea rotundata menyukai perairan yang terpapar sinar matahari, jenis lamun tersebut merupakan jenis lamun yang kosmopolit, yaitu dapat tumbuh hampir di semua kategori habitat. Pada stasiun I, daerah ini merupakan daerah dangkal yang terpapar sinar matahari. Selain itu, aktivitas manusia pada stasiun I sebagian besar berada di pesisir pantai sehingga tidak begitu mempengaruhi pertumbuhan lamun ini.

Tabel 7

Kerapatan jenis lamun setiap stasiun

\begin{tabular}{cccc}
\hline \multirow{2}{*}{ Spesies Lamun } & \multicolumn{3}{c}{ Kerapatan Jenis (ind $/ \mathrm{m}^{2}$ ) } \\
\cline { 2 - 4 } & Stasiun I & Stasiun II & Stasiun III \\
\hline Enhalus Acoroides & - & 57 & 33 \\
Thalassia hemprichii & 58 & 4 & - \\
Cymodocea & 777 & 111 & 107 \\
$\quad$ rotundata & & & \\
Halophila ovalis & 58 & 55 & 116 \\
Halodule pinifolia & 709 & 15 & 201 \\
$\quad \begin{array}{c}\text { Syringodium } \\
\text { isoetifolium }\end{array}$ & 244 & - & - \\
Thalassodendron & 42 & - & - \\
ciliatum & & & \\
\hline TOTAL & 1888 & 242 & 457 \\
\hline
\end{tabular}

Kerapatan lamun Cymodocea rotundata pada stasiun I memiliki perbedaan jumlah yang sangat signifikan dengan stasiun lainnya. Menurut Wicaksono (2012), jenis Cymodocea rotundata menyukai perairan yang terpapar sinar matahari, jenis lamun tersebut merupakan jenis lamun yang kosmopolit, yaitu dapat tumbuh hampir di semua kategori habitat. Pada stasiun I, daerah ini merupakan daerah dangkal yang terpapar sinar matahari. Selain itu, aktivitas manusia pada stasiun I sebagian besar berada di pesisir pantai sehingga tidak begitu mempengaruhi pertumbuhan lamun ini.

Jenis lamun Thalassia hemprichii pada stasiun II memiliki tingkat kerapatan terendah 
dibandingkan dengan jenis lainnya yaitu hanya 4 ind $/ \mathrm{m}^{2}$. Hal ini kemungkinan karena penyebaran distribusi Thalassia hemprichii yang sempit yang hanya bisa tumbuh sampai kedalaman $5 \mathrm{~cm}$.

\subsubsection{Persentase Tutupan Lamun}

Persentase tutupan lamun menggambarkan seberapa luas lamun yang menutupi suatu perairan. Penutupan jenis lamun paling tinggi yaitu jenis Cymodocea rotundata pada stasiun I dengan nilai persentase penutupan sebesar $39,27 \% / \mathrm{m}^{2}$. Nilai penutupan jenis terendah yaitu jenis Thalassia hemprichii pada stasiun II dengan persentase penutupan yaitu $0,28 \% / \mathrm{m}^{2}$ (Tabel 8 ).

Tabel 8

Persentase tutupan lamun

\begin{tabular}{cccc}
\hline \multirow{2}{*}{ Spesies Lamun } & \multicolumn{3}{c}{ Penutupan Jenis $\left(\% / \mathrm{m}^{2}\right)$} \\
\cline { 2 - 4 } & Stasiun I & Stasiun II & Stasiun III \\
\hline Enhalus acoroides & - & 4,22 & 4,17 \\
Thalassia hemprichii & 3,44 & 0,28 & - \\
$\quad$ Cymodocea & 39,27 & 6,75 & 5,04 \\
$\quad$ rotundata & & & \\
Halophila ovalis & 1,96 & 1,74 & 3,73 \\
Halodule pinifolia & 21,46 & 0,66 & 7,85 \\
$\quad$ Syringodium & 10,06 & - & - \\
isoetifolium & & & - \\
Thalassodendron & 3,36 & - & - \\
$\quad$ ciliatum & & & \\
\hline TOTAL & 79,55 & 13,65 & 20,79 \\
\hline
\end{tabular}

Hasil pengamatan yang didapatkan pada seluruh stasiun, nilai persentase penutupan yang paling tinggi terdapat pada stasiun I, yakni sebesar $79,55 \%$. Kemudian pada stasiun III yaitu $20,79 \%$ dan yang terendah pada stasiun II yaitu $13,65 \%$. Berdasarkan Kepmen LH nomor 200 Tahun 2004, stasiun I tergolong dalam kondisi baik yaitu padang lamun yang kaya dan sehat (nilai perssen tutupan $>60 \%$ ), stasiun II dan stasiun III tergolong dalam kondisi rusak yaitu padang lamun miskin (nilai persen tutupan $<29,9 \%$ ). Menurut Simon et al. (2013), tutupan lamun berhubungan erat dengan habitat atau bentuk morfologi dan ukuran suatu spesies lamun. Kepadatan yang tinggi dan kondisi pasang surut saat pengamatan juga dapat mempengaruhi nilai estimasi penutupan lamun.

Daerah yang telah terganggu aktivitas manusia memiliki persen penutupan paling kecil dan penutupan lamun akan semakin tinggi pada daerah yang alami (Adli, 2016). Pada stasiun II terdapat aktivitas budidaya rumput laut.
Sementara pada stasiun III yang berbatasan langsung dengan kawasan wisata bahari Tanjung Benoa dan Pelabuhan Benoa menjadikan stasiun ini padat aktivitas manusia karena sering dilewati oleh speed boat kegiatan pariwisata dan kapal-kapal besar yang hendak menuju ke Pelabuhan Benoa. Menurut Sudiarta (2011), kegiatan budidaya rumput laut di Pulau Serangan menggunakan metode lepas dasar dan metode apung menutupi dan menghilangkan lamun sehingga lamun cenderung mengalami kematian. Propeler (balingbaling) boat, lalu lintas boat bermesin pada areal padang lamun menimbulkan kerusakan pada daun lamun.

\subsection{Pengaruh Kualitas Perairan terhadap Persentase Tutupan Lamun}

Berdasarkan hasil pengukuran parameter kualitas Perairan Pulau Serangan untuk suhu, salinitas dan $\mathrm{pH}$ pada seluruh stasiun pengamatan masih tergolong dalam standar baku mutu air laut untuk lamun berdasarkan Kepmen LH No. 51 tahun 2004 (Tabel 9). Suhu Perairan Pulau Serangan berkisar antara $28,25^{\circ} \mathrm{C}-29,7^{\circ} \mathrm{C}$. Kemudian salinitas Perairan Pulau Serangan berada pada kisaran 30 ppt - 31 ppt dan $\mathrm{pH}$ berkisar antara 7,8 $-7,9$.

Tabel 9.

Hasil pengukuran kualitas Perairan Pulau Serangan

\begin{tabular}{ccccc}
\hline \multirow{2}{*}{ No. } & Parameter & \multicolumn{3}{c}{ Stasiun } \\
& & I & II & III \\
\hline 1 & Suhu $\left({ }^{\circ} \mathrm{C}\right)$ & 28,25 & 28,55 & 29,7 \\
2 & Salinitas (ppt) & 31 & 31 & 30 \\
3 & pH & 7,8 & 7,8 & 7,9 \\
4 & Kekeruahan (NTU) & 0,66 & 5,13 & 5,53 \\
5 & Nitrat $(\mathrm{mg} / \mathrm{l})$ & 0,17 & 0,59 & 0,44 \\
6 & Fosfat $(\mathrm{mg} / \mathrm{l})$ & 0,01 & 0,46 & 0,12 \\
\hline
\end{tabular}

Hasil pengukuran kekeruhan dan fosfat hanya pada stasiun I saja yang masih berada dalam standar baku mutu air laut untuk biota laut yaitu 0,66 NTU, sedangkan kadar kekeruhan dan fosfat pada stasiun II dan stasiun III sudah melebihi standar baku mutu dimana kekeruhan harus $<5$ NTU dan fosfat 0,015 mg/l. Kandungan nitrat pada seluruh stasiun pengamatan juga sudah melebihi standar baku mutu (melebihi 0,008 $\mathrm{mg} / \mathrm{l}$ ) yaitu berkisar antara 0,17-0,59 NTU. 

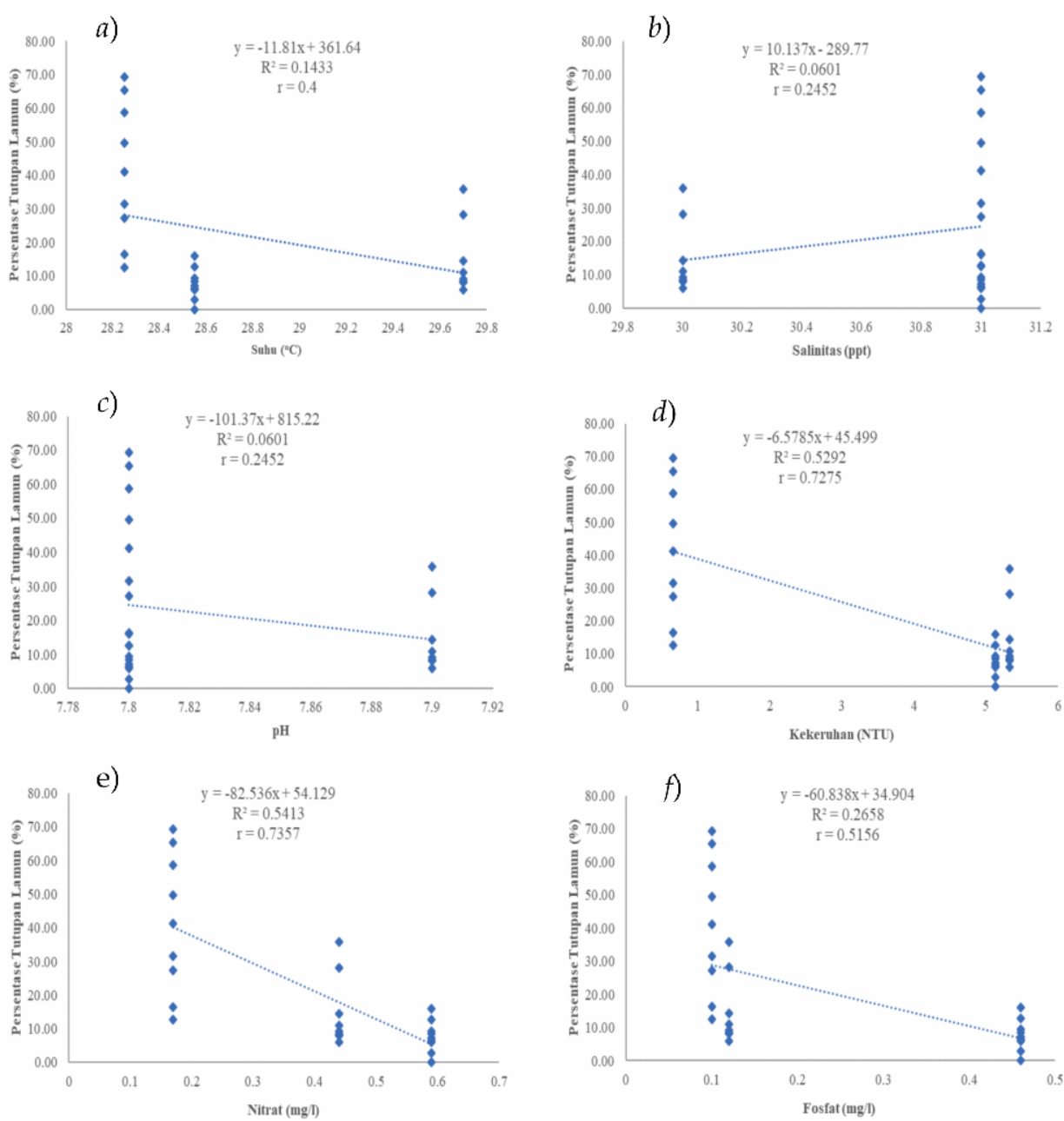

Gambar 2. Regresi kualitas perairan terhadap persen tutupan lamun: a) suhu, b) salinitas, c) pH, d) kekeruhan, e) nitrat, dan f) fosfat

Pengamatan substrat secara visual didapatkan hasil yaitu stasiun I memiliki substrat yang beragam seperti pasir putih, pasir berbatu, dan yang mendominasi yaitu substrat karang berpasir. Stasiun II hanya didominasi oleh substrat pasir agak berlumpur. Sementara untuk stasiun III memiliki substrat yang beragam yaitu pasir putih halus, pasir berlumpur, karang berpasir dan yang mendominasi yaitu pasir berlumpur bercampur pecahan-pecahan karang mati disekitar lokasi tersebut. Perairan Pulau Serangan merupakan perairan yang produktif dan memiliki berbagai jenis substrat, seperti: substrat berpasir halus, substrat pasir putih berlumpur kasar serta bercampur dengan pecahan karang (Saraswati et al., 2017 dan Herlinawati et al., 2018).

Berdasarkan hasil analisis regresi linear diperoleh hasil persamaan regresi linear yang memiliki korelasi positif terhadap persen tutupan lamun hanya pada salinitas yang berarti persen tutupan lamun akan mengalami peningkatan bila kandungan salinitas meningkat. Sedangkan suhu, $\mathrm{pH}$, kekeruhan, nitrat dan fosfat memiliki korelasi negatif terhadap persen tutupan lamun. Jika suhu, $\mathrm{pH}$, kekeruhan, nitrat dan fosfat mengalami kenaikan maka akan menunjukkan hubungan terbalik dengan persen tutupan lamun, begitu juga sebaliknya (Gambar 2).

Hasil rumus persamaan regresi salinitas $\mathrm{Y}=$ $10,137 x-289,77$ yang memiliki nilai korelasi positif menujukkan bahwa setiap peningkatan 1 satuan salinitas perairan akan menyebabkan peningkatan persen tutupan lamun sebesar 10,137\%. Hasil rumus persamaan regresi parameter kualitas perairan lainnya seperti suhu $\mathrm{Y}=-11,81 \mathrm{x}+361,64$, pH $Y=-101,37 x+815,22$, kekeruhan $Y=-6,5785 x+$ 45,4999 , nitrat $Y=-82,536 x+54,129$ dan fosfat $Y=-$ $60,838 x+34,904$ memiliki nilai korelasi negatif.

Parameter suhu, $\mathrm{pH}$, kekeruhan, nitrat dan fosfat yang memiliki korelasi negatif dapat 
diartikan bahwa setiap peningkatan 1 satuan suhu perairan akan mengakibatkan penurunan persen tutupan lamun sebesar $11,81 \%$. Untuk parameter $\mathrm{pH}$, setiap peningkatan 1 satuannya akan mengakibatkan penurunan persen tutupan lamun sebesar 101,37\%. Pada parameter kekeruhan setiap peningkatan 1 satuannya akan mengakibatkan penurunan persen tutupan lamun sebesar 6,5785\%, parameter nitrat setiap peningkatan 1 satuan nitrat akan mengakibatkan penurunan persen tutupan lamun sebesar $82,536 \%$, serta setiap peningkatan 1 satuan fosfat akan mengakibatkan penurunan persen tutupan lamun sebesar $60,838 \%$.

Berdasarkan hasil regresi antara suhu dengan persentase tutupan lamun memiliki koefisien determinasi sebesar 0,1433. Hal ini berarti suhu mempengaruhi persen tutupan lamun sebesar $14 \%$. Hubungan suhu dengan persen tutupan lamun memiliki hubungan yang cukup ditunjukkan dengan nilai koefisien korelasinya yaitu 0.4. Selanjutnya regresi antara salinitas dan $\mathrm{pH}$ dengan persentase tutupan lamun pada ketiga stasiun memiliki nilai koefisien determinasi 0,0601. Diantara parameter kualitas air yang lain, salinitas dan $\mathrm{pH}$ merupakan parameter yang memiliki pengaruh yang sangat kecil terhadap persen tutupan lamun yaitu hanya $6 \%$ saja. Hubungan salinitas dan $\mathrm{pH}$ terhadap persen tutupan lamun memiliki hubungan yang lemah yaitu dengan koefisien korelasinya 0,2452.

Hasil perhitungan regresi antara kekeruhan dengan persentase tutupan lamun memberi pengaruh cukup besar dibandingkan dengan parameter kualitas air lainnya. Hasil regresi menujukkan koefisien determinasi sebesar 0,5292. Hal ini menjelaskan bahwa kekeruhan berpengaruh terhadap persen tutupan lanun di tiga stasiun sebesar $53 \%$ dan $47 \%$ sisanya dipengaruhi oleh faktor lain. Nilai koefisien korelasi kekeruhan yaitu $R=0,7275$ yang berarti kekeruhan memiliki hubungan yang kuat terhadap persentase tutupan lamun.

Nilai koefisien korelasi nitrat yaitu sebesar 0,7375, sama halnya seperti parameter kekeruhan, nitrat memiliki hubungan yang kuat terhadap persen tutupan lamun. Nitrat mempengaruhi persen tutupan lamun sebesar 54\% yang ditunjukkan dengan nilai koefisien determinasinya yaitu 0,5413 . Nitrat menjadi parameter kualitas air yang memiliki pengaruh paling tinggi terhadap persen tutupan lamun dibandingkan dengan parameter kualitas air lainnya. Sementara hasil analisis regresi untuk fosfat memiliki hubungan yang cukup terhadap persen tutupan lamun. Hal ini ditunjukkan dengan nilai koefisien korelasinya yaitu 0.5156. Nilai koefisien determinasi fosfat yaitu 0.2658 . Hal ini menunjukkan bahwa fosfat mempengaruhi persen tutupan lamun sebesar $27 \%$.

Hasil regresi kekeruhan memiliki selisih nilai $1 \%$ dengan regresi nitrat, hal ini juga menjadikan kekeruhan sebagai salah satu parameter kualitas air yang memiliki pengaruh yang cukup besar setelah nitrat terhadap persen tutupan lamun. Nilai kekeruhan yang tinggi dapat mengakibatkan berkurangnya penetrasi cahaya kedalam perairan sehingga menghambat laju fotosintesis. Kekeruhan di perairan dapat berasal dari bahan-bahan tersuspensi seperti lumpur, pasir, plankton, dan organisme mikroskopik lainnya (Yuliana, 2014).

Menurut Suryanto et al. (2014), pertumbuhan, morfologi, kelimpaham dan produktivitas primer lamun pada suatu perairan umumnya ditentukan oleh ketersediaan zat hara yang salah satunya adalah nitrat. Nitrat merupakan salah satu nutrien penting yang dibutuhkan oleh organisme laut (Dewanti, 2018). Nitrat merupakan contoh nutrien yang dominan terdapat dalam suatu perairan yang digunakan oleh fitoplankton dan biota lainnya seperti lamun dalam proses rantai makanan (Simanjuntak, 2012).

\section{Simpulan}

Lamun yang ditemukan di Perairan Pulau Serangan terdiri dari 7 spesies yaitu Enhalus acoroides, Thalassia hemprichii, Cymodocea rotundata, Halophila ovalis, Halodule pinifolia, Syringodium isoetifolium, dan Thalassodendron ciliatum dengan nilai indeks keanekaragaman termasuk kedalam kategori sedang.

Kerapatan padang lamun Perairan Pulau Serangan tergolong dalam skala kondisi 5 yaitu sangat rapat $\left(>175 \mathrm{ind} / \mathrm{m}^{2}\right)$ dengan kerapatan jenis tertinggi yaitu Cymodocea rotundata pada stasiun I dengan jumlah $777 \mathrm{ind} / \mathrm{m}^{2}$. Nilai persentase tutupan lamun tertinggi terdapat pada stasiun I yang tergolong dalam kondisi baik yakni sebesar $79,55 \%$, stasiun II dan stasiun III tergolong dalam kondisi rusak dengan nilai 13,65\% dan 20,79\%.

Parameter kualitas Perairan Pulau Serangan menunjukkan pengaruh yang relatif rendah terhadap persen tutupan lamun yaitu mulai dari nilai yang paling rendah yakni salinitas dan $\mathrm{pH}$ 
yang hanya memberikan pengaruh sebesar $6 \%$, suhu sebesar $14 \%$, fosfat sebesar $27 \%$, kekeruhan sebesar $53 \%$ dan yang paling tinggi yaitu nitrat sebesar $54 \%$.

\section{Ucapan terimakasih}

Penulis mengucapkan terima kasih kepada seluruh pihak yang telah memberikan masukan dan bimbingan dalam pembuatan jurnal ilmiah ini. Terimakasih yang sebesar - besarnya kepada Fakultas Kelautan dan Perikanan atas fasilitas yang telah diberikan.

\section{Daftar Pustaka}

Adli, A., Rizal, A., \& Ya'la, Z. R. (2016). Profil ekosistem lamun sebagai salah satu indikator kesehatan pesisir Perairan Sabang Tende Kabupaten Tolitoli. Jurnal Sains dan Teknologi Tadulako, 5(1), 49-62.

Alie, K. (2012). Pertumbuhan dan biomassa lamun Thalassia hemprichii di perairan Pulau Bone Batang, Kepulauan Spermonde, Sulawesi Selatan. Jurnal MIP A FMIP A Universitas Lampung, 16(2), 105-110.

Ardiani, D. K., Dharmayanti, A. W. S., \& Pujiastuti, P. (2014). Kadar fosfor (p) dalam cairan sulkus gingiva pada penderita penyakit periodontal phosphorus $(p)$ level of gingival crevicular fluid of peridontal diseases. Insisiva Dental Journal, 3(1), 1-9.

Dewanti, L. P. P., Putra, I D. N. N., \& Faiqoh, E. (2018). Hubungan kelimpahan dan keanekaragaman fitoplankton dengan kelimpahan dan keanekaragaman zooplankton di Perairan Pulau Serangan, Bali. Journal of Marine and Aquatic Science, 4(2), 324-335.

Faiqoh, E., Wiyanto, D. B., \& Astrawan, I. G. B. (2017). Peranan padang lamun selatan bali sebagai pendukung kelimpahan ikan di Perairan Bali. Journal of Marine and Aquatic Science, 3(1), 10-18.

Haris, A., \& Gosari, J. A. (2012). Studi kerapatan dan penutupan jenis lamun di Kepulauan Spermonde. Torani. Jurnal Ilmu Kelautan dan Perikanan, 22(3), 256162.

Hartati, R., Djunaedi, A., Hariyadi, H., \& Mujiyanto, M. (2012). Struktur komunitas padang lamun di Perairan Pulau Kumbang, Kepulauan Karimunjawa. Ilmu Kelautan: Indonesian Journal of Marine Sciences, 17(4), 217-225.

Hartati, R., Widianingsih, W., Santoso, A., Endrawati, H., Zainuri, M., Riniatsih, I., Saputra, W. L., \& Mahendrajaya, R. T. (2017). Variasi komposisi dan kerapatan jenis lamun di Perairan Ujung Piring, Kabupaten Jepara. Jurnal Kelautan Tropis, 20(2), 96-105.

Herlinawati, N. D. P. D., Arthana, I. W., \& Dewi, A. P. W. K. (2018). Keanekaragaman dan kerapatan rumput laut alami Perairan Pulau Serangan Denpasar Bali. Journal of Marine and Aquatic Science, 4(1), 22-30

Kusumaningtyas, D. I. (2010). Analisis kadar nitrat dan klasifikasi tingkat kesuburan di Perairan Waduk Ir. H. Djuanda, Jatiluhur, Purwakarta. Buletin Teknik Litkayasa Sumber Daya dan Penangkapan, 8(2), 49-54.

McKenzie, L. J. (2003). Guidelines for the rapid assessment and mapping of tropical seagrass habitats. Department of Primary Industries. The State of Queensland.

MNLH. (2004). Keputusan Menteri Negara Lingkungan Hidup Nomor: 51 Tahun 2004 tentang Baku Mutu Air Laut. Jakarta-Indonesia. Menteri Negara Lingkungan Hidup Republik Indonesia.

MNLH. (2004). Salinan Keputusan Menteri Lingkungan Hidup Nomor 200 tentang Kriteria Baku Kerusakan dan Pedoman Penentuan Status Padang Lamun. JakartaIndonesia. Menteri Negara Lingkungan Hidup Republik Indonesia.

Mulyadi, M. (2011). Penelitian kuantitatif dan kualitatif serta pemikiran dasar menggabungkannya. Jurnal studi komunikasi dan media, 15(1), 128-137.

Odum, E. P. (1993). Dasar-dasar Ekologi. Edisi Ketiga. Diterjemahkan oleh T. Samingan. Yogyakarta: Gadjah Mada University Press.

Rahardiarta, I K. V. S, Putra, I D. N. N., Suteja, Y. (2019) Simpanan karbon pada padang lamun di Kawasan Pantai Mengiat, Nusa Dua Bali. Journal of Marine and Aquatic Science, 5(1), 1-10.

Rahman, A. A., Nur, A. I., \& Ramli, M. (2016). Studi laju pertumbuhan lamun (Enhalus acoroides) di Perairan Pantai Desa Tanjung Tiram Kabupaten Konawe Selatan. Jurnal Sapa Laut (Jurnal Ilmu Kelautan), 1(1), 10-16.

Sakaruddin, M. I. (2011). Komposisi Jenis, Kerapatan, Persen Penutupan dan Luas Penutupan Lamun di Perairan Pulau Panjang Tahun 1990 - 2010. Skripsi. Bogor: Fakultas Perikanan dan Ilmu Kelautan, Institut Pertanian Bogor.

Saraswati, N. L. G. R. A., Arthana, I. W., \& Hendrawan, I. G. (2017). Analisis kualitas perairan pada wilayah Perairan Pulau Serangan Bagian Utara berdasarkan baku mutu air laut. Journal of Marine and Aquatic Science, 3(2), 163-170.

Simanjuntak, M. (2012). Kualitas air laut ditinjau dari aspek zat hara, oksigen terlarut dan $\mathrm{pH}$ di Perairan Banggai, Sulawesi Tengah. Jurnal Ilmu dan Teknologi Kelautan Tropis, 4(2), 290-303.

Simon, I. P., \& Rifai, H. (2013). Struktur komunitas padang lamun di Perairan Pulau Mantehage, Sulawesi Utara. Jurnal Ilmiah Platax, 1(4), 177-186.

Sudiarta, I K., \& Restu, I W. (2011). Kondisi dan strategis pengelolaan komunitas padang lamun di wilayah pesisir Kota Denpasar, Provinsi Bali. Jurnal Bumi Lestari, II (2), 195-207. 
Sugiyono. (2012). Metode Penelitian Kuantitatif Kualitatif dan REB. Bandung: Alfabeta.

Suryanto, A., Purwanti, F., \& Minerva, A. (2014). Analisis hubungan keberadaan dan kelimpahan lamun dengan kualitas air di Pulau Karimunjawa Jepara. Diponegoro Journal of Maquares, 3(1), 88-94.

Tangke, U. (2010). Ekosistem padang lamun (manfaat, fungsi dan rehabilitasi). Agrikan: Jurnal Ilmiah Agribisnis dan Perikanan, 3(1), 9-29.

Tishmawati, R. N. C., \& Ain, C. (2014). Hubungan kerapatan lamun (seagrass) dengan kelimpahan syngnathidae di Pulau Panggang Kepulauan Seribu. Management of Aquatic Resources Journal, 3(4), 147-153.

Ulfa, M., Julyantoro, P. G. S., \& Sari, A. H. W. (2018). Keterkaitan komunitas makrozoobentos dengan kualitas air dan substrat di ekosistem mangrove
Taman Hutan Raya Ngurah Rai Bali. Journal of Marine and Aquatic Sciences, 4(2), 179-190.

Wagey, B. T. (2013). Morphometric analisis of seagrass species in Negros Oriental. Jurnal Ilmiah Sains, 13(2), 93-97.

Wicaksono, S. G., \& Widianingsih, S. T. H. (2012). Struktur vegetasi dan kerapatan jenis lamun di Perairan Kepulauan Karimunjawa Kabupaten Jepara. Journal of Marine Research, 1(2), 1-7.

Yuliana, Y. (2014). Keterkaitan antara kelimpahan zooplankton dengan fitoplankton dan parameter fisika-kimia di Perairan Jailolo, Halmahera Barat. Maspari Journal, 6(1), 25-31.

Yusniati, Y. (2015). Jenis-jenis lamun di Perairan Laguna Tasilaha dan pengembangannya sebagai media pembelajaran biologi. Jurnal Sains dan Teknologi Tadulako, 4(1), 13-22.

(c) 2018 by the authors; licensee Udayana University, Indonesia. This article is an open access article distributed under the terms and conditions of the Creative Commons Attribution license (http://creativecommons.org/licenses/by/3.0/). 